\title{
KEPUASAN PASIEN TERHADAP PELAYANAN KESEHATAN: STUDI DESKRIPTIF PADA KLINIK JANTUNG HASNA MEDIKA INDRAMAYU
}

\author{
Patient Satisfaction on The Health Services: \\ A Descriptive Study at Hasna Medika Indramayu Heart Clinic \\ Meddy Nurpratama \\ meddynurpratamafe@unwir.ac.id \\ Manajemen FE, Universitas Wiralodra
}

\begin{abstract}
Abstrak
Keberadaan kualitas pelayanan yang selaras dengan keinginan pasien akan berefek positif bagi keberlanjutan Klinik Jantung Hasna Medika Indramayu. Oleh karena itu, penelitian ini bertujuan memberikan gambaran kepuasan pasien terhadap pelayanan kesehatan di Klinik Jantung Hasna Medika Indramayu. Studi yang digunakan dalam penelitian ini berbasis survei. Pendekatan yang digunakan bersifat deskriptif. Populasi dalam penelitian ini yaitu pasien yang berkunjung di Klinik Jantung Hasna Medika Indramayu selama bulan Maret-April 2019. Tehnik sampling yang digunakan adalah accidental sampling. Sebanyak 30 responden rawat jalan dan 30 responden rawat inap diambil sebagai sampel penelitian. Tehnik pengambilan data dengan kuesioner. Penyajian data melalui tabel distribusi frekuensi (grafik). Hasil penelitian didapatkan bahwa pencapaian kepuasan tertinggi pada pelayanan rawat jalan di Klinik Jantung Hasna Medika Indramayu yaitu penampilan dokter, perawat dan karyawan lainnya bersih dan rapih $(88,3 \%)$ sedangkan rawat inap yaitu prosedur penerimaan pasien dilayani secara cepat dan tidak berbelit-belit $(83,3 \%)$. Sebagian besar pelayanan di Klinik Jantung Hasna Medika Indramayu baik rawat jalan maupun rawat inap sudah memuaskan pasien. Sementara pelayanan yang kurang memuaskan terdapat pada pelayanan rawat jalan yaitu waktu pelayanan dan kenyamanan ruang tunggu, kelengkapan fasilitas di ruang tunggu pasien, prosedur penerimaan pasien dilayani secara cepat dan tidak berbelit-belit dan dokter datang tepat waktu. Diharapkan penelitian ini bisa dikembangkan oleh peneliti selanjutnya agar kualitas dan kuantitas pelayanan di Klinik Jantung Hasna Medika Indramayu agar semakin lebih baik.
\end{abstract}

Kata Kunci: Kepuasan Pasien, Pelayanan Kesehatan

\section{PENDAHULUAN}

Kualitas pelayanan yang sesuai dengan harapan pasien tentunya akan memberikan

\begin{abstract}
The existence of quality services that are in harmony with the wishes of patients will have a positive effect on the sustainability of the Hasna Medika Indramayu Heart Clinic. Therefore, this study aims to provide an overview of patient satisfaction with health services at Hasna Medika Indramayu Heart Clinic. The study used in this study was survey based. The approach used is descriptive. The population in this study were patients who visited the Hasna Medika Indramayu Heart Clinic during March-April 2019. The sampling technique used was accidental sampling. A total of 30 respondents were outpatient and 30 inpatients were taken as research samples. Techniques for collecting data with questionnaires. Presentation of data through frequency distribution table (graph). The results showed that the highest achievement of outpatient care in the Heart Clinic of Hasna Medika Indramayu was the appearance of clean and neat doctors, nurses and other employees $(88.3 \%)$ while inpatient care, namely the patient admission procedure served quickly and not convoluted (83.3\%). Most services at the Hasna Medika Indramayu Heart Clinic both outpatient and inpatient care have satisfied patients. While unsatisfactory services are in outpatient services, namely service time and comfort of the waiting room, complete facilities in the patient's waiting room, patient admissions procedures are served quickly and not convoluted and the doctor arrives on time. It is hoped that this research can be developed by further researchers so that the quality and quantity of services in the Hasna Medika Indramayu Heart Clinic will be even better.
\end{abstract}

Keywords: Patient Satisfaction, Health Services

dampak positif dalam penyelenggaraan kesehatan di Klinik Jantung Hasna Medika Indramayu, dikarenakan dengan adanya kepuasan pada pasien akan terjalin hubungan 
Meddy Nurpratama

yang harmonis antara klinik dan pasien, pasien memiliki loyalitas terhadap klinik serta rekomendasi dari mulut ke mulut oleh pasien kepada orang lain. Kepuasan terhadap pelayanan dalam bidang kesehatan tersebut haruslah dirasakan seluruh pasien yang berkunjung ke klinik baik mahasiswa, civitas akademika maupun pasien umum (masyarakat) pada semua jenis pelayanan yang ada di klinik baik rawat jalan maupun rawat inap.

Dimensi mutu ada dua yaitu mutu teknis dan fungsional, yang termasuk dalam kualitas teknis adalah Search Quality, Experience Quality, Credence Quality sedangkan yang termasuk dalam kualitas fungsional adalah RATER: reliability (keterandalan), assurance (jaminan), tangible (nyata), empathy (empati), dan responsiveness (cepat tanggap) (Supriyanto dan Wulandari, 2011). Delapan dimensi mutu pelayanan pelayanan kesehatan yaitu respect and caring (rasa menghargai dan kepedulian), effectiveness and continuity (efektivitas dan keberlanjutan), appropriateness (kelayakan), information (informasi), efficiency (efisiensi), meals (makanan), first impression (kesan pertama), staff diversity (komposisi pegawai) (Sower, 2006). Dengan dimensi tersebut, akan dapat diketahui kepuasan pasien di Klinik Jantung Hasna Medika Indramayu.

Klinik Jantung Hasna Medika Indramayu berlokasi di Jalan Raya KM 150 Langut Lohbener Kabupaten Indramayu Jawa
Barat. Klinik Jantung Hasna Medika Indramayu adalah wujud komitmen Hasna Medika Group dalam mendekatkan pelayanan kesehatan jantung kepada masyarakat, Dimanifestasikan akan menjadi Rumah Sakit Jantung. Klinik Jantung Hasna Medika Indramayu terdiri dari RS Jantung Hasna Medika Palimanan Cirebon dan RS Jantung Hasna Medika Kuningan. Berikut adalah pencapaian kunjungan pasien Klinik jantung Hasna Medika Indramayu :

Gambar 1.

Pencapaian Kunjungan Pasien Rawat Jalan dan Rawat Inap di

Klinik Jantung Hasna Medika Indramayu ( Januari 2019 - Maret 2019)

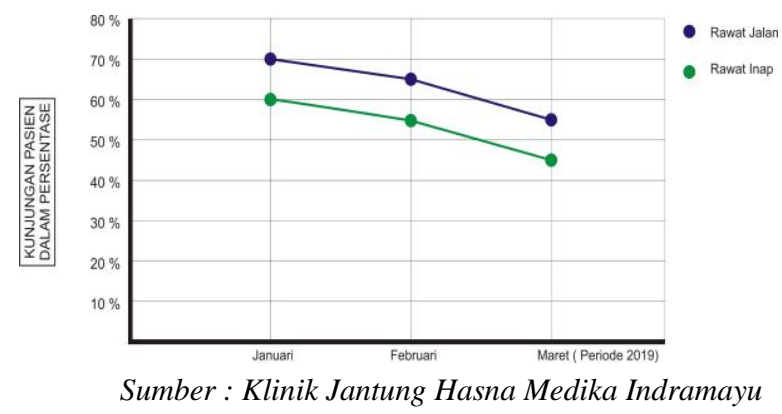

Berdasarkan paparan di atas, nampak penurunan kunjungan pasien rawat jalan sebesar (55\%) dan rawat inap sebesar (45\%) pada Klinik Jantung Hasna Medika Indramayu dari bulan Januari sampai dengan Maret 2019, maka dari itu penulis perlu mengadakan adanya survei tingkat kepuasan pasien di Klinik Jantung Hasna Medika Indramayu baik rawat jalan maupun rawat inap. Penelitian ini memiliki tujuan untuk mengetahui tingkat kepuasan pasien terhadap pelayanan kesehatan di Klinik Jantung Hasna Medika Indramayu. 
Meddy Nurpratama

\section{METODE PENELITIAN}

Penelitian ini merupakan penelitian survei dan menggunakan pendekatan deskriptif. Populasi dalam penelitian ini adalah seluruh pasien rawat jalan dan rawat inap di Klinik Jantung Hasna Medika Indramayu periode bulan Maret 2019. Teknik Sampling yang digunakan adalah dengan accidental sampling, diperoleh sampel sebanyak 30 pasien rawat jalan dan 30 pasien rawat inap. Penelitian ini dilakukan di Klinik Jantung Hasna Medika Indramayu dengan alasan pemilihan lokasi penelitian adalah karena belum pernah dilakukan penelitian serupa sebelumnya. Waktu penelitian adalah tanggal 4 Maret sampai 13 April 2019. Teknik pengumpulan data diperoleh dari pembagian kuesioner yang dibagikan kepada pasien rawat jalan dan rawat inap di Klinik Jantung Hasna Medika Indramayu untuk memperoleh gambaran tentang kepuasan pasien terhadap pelayanan kesehatan di Klinik Jantung Hasna Medika Indramayu. Hasil pengumpulan data disajikan dengan tabel distribusi frekuensi dan narasi.

\section{HASIL DAN PEMBAHASAN}

Berdasarkan hasil penelitian yang ditelah dilakukan mengenai kepuasan pasien dengan menyebarkan kuesioner kepada pasien rawat jalan sebanyak 30 orang dan rawat jalan sebanyak 30 orang didapatkan hasil sebagai berikut ini. Adapun gambaran tentang kepuasan pasien rawat jalan di Klinik Jantung Hasna Medika Indramayu dapat dilihat pada tabel 1.

Tabel 1

Distribusi Frekuensi Tanggapan Responden Rawat Jalan tentang Pelayanan di Klinik Jantung Hasna Medika Indramayu

\begin{tabular}{|c|c|c|c|c|c|c|c|c|c|c|c|c|c|}
\hline \multirow{3}{*}{ No. } & \multirow{3}{*}{ Pertanyaan } & \multicolumn{10}{|c|}{ Jawaban } & \multirow{2}{*}{\multicolumn{2}{|c|}{$\begin{array}{c}\text { Jumlah } \\
\text { Total }\end{array}$}} \\
\hline & & \multicolumn{2}{|c|}{\begin{tabular}{|c|} 
Sangat \\
Tidak \\
Memuaskan
\end{tabular}} & \multicolumn{2}{|c|}{$\begin{array}{c}\text { Tidak } \\
\text { Memuaskan }\end{array}$} & \multicolumn{2}{|c|}{$\begin{array}{c}\text { Kurang } \\
\text { Memuaskan }\end{array}$} & \multicolumn{2}{|c|}{ Memuaskan } & \multicolumn{2}{|c|}{$\begin{array}{c}\text { Sangat } \\
\text { memuaskan }\end{array}$} & & \\
\hline & & $\mathbf{F}$ & $\%$ & $\mathbf{F}$ & $\%$ & $\mathbf{F}$ & $\%$ & $\mathbf{F}$ & $\%$ & $\mathbf{F}$ & $\%$ & $\mathbf{F}$ & $\%$ \\
\hline 1 & $\begin{array}{l}\text { Waktu Pelayanan dan } \\
\text { Kenyamanan Ruang Tunggu }\end{array}$ & 0 & 0 & 3 & 10.0 & 20 & 66.7 & 4 & 13.3 & 3 & 10.0 & 30 & 100 \\
\hline 2 & $\begin{array}{l}\text { Penampilan Dokter, Perawat dan } \\
\text { Karyawan lainnya Bersih dan } \\
\text { Rapih }\end{array}$ & 0 & 0 & 0 & 0.0 & 0 & 0.0 & 25 & 83.3 & 5 & 16.7 & 30 & 100 \\
\hline 3 & $\begin{array}{l}\text { Kelengkapan Fasilitas di Ruang } \\
\text { Tunggu Pasien }\end{array}$ & 0 & 0 & 0 & 0.0 & 21 & 70.0 & 6 & 20.0 & 3 & 10.0 & 30 & 100 \\
\hline 4 & $\begin{array}{l}\text { Memiliki alat-alat } \\
\text { Medis/kesehatan yang cukup } \\
\text { lengkap }\end{array}$ & 0 & 0 & 0 & 0.0 & 3 & 10.0 & 22 & 73.3 & 5 & 16.7 & 30 & 100 \\
\hline 5 & $\begin{array}{l}\text { Kenyaman di Ruangan Kontrol } \\
\text { Dokter dan ruang rawat inap }\end{array}$ & 0 & 0 & 0 & 0.0 & 6 & 20.0 & 20 & 66.7 & 4 & 13.3 & 30 & 100 \\
\hline 6 & $\begin{array}{l}\text { Kebersihan dan Keamanan di } \\
\text { ruang lingkup dalam dan di luar } \\
\text { klinik }\end{array}$ & 0 & 0 & 0 & 0.0 & 3 & 10.0 & 20 & 66.7 & 7 & 23.3 & 30 & 100 \\
\hline 7 & $\begin{array}{l}\text { Prosedur penerimaan pasien } \\
\text { dilayani secara cepat dan tidak } \\
\text { berbelit-belit }\end{array}$ & 0 & 0 & 0 & 0.0 & 22 & 73.3 & 6 & 20.0 & 2 & 6.7 & 30 & 100 \\
\hline
\end{tabular}


Meddy Nurpratama

\begin{tabular}{|c|c|c|c|c|c|c|c|c|c|c|c|c|c|}
\hline \multirow{3}{*}{ No. } & \multirow{3}{*}{ Pertanyaan } & \multicolumn{10}{|c|}{ Jawaban } & \multirow{2}{*}{\multicolumn{2}{|c|}{$\begin{array}{l}\text { Jumlah } \\
\text { Total }\end{array}$}} \\
\hline & & \multicolumn{2}{|c|}{\begin{tabular}{|c|} 
Sangat \\
Tidak \\
Memuaskan
\end{tabular}} & \multicolumn{2}{|c|}{$\begin{array}{c}\text { Tidak } \\
\text { Memuaskan }\end{array}$} & \multicolumn{2}{|c|}{$\begin{array}{c}\text { Kurang } \\
\text { Memuaskan }\end{array}$} & \multicolumn{2}{|c|}{ Memuaskan } & \multicolumn{2}{|c|}{$\begin{array}{c}\text { Sangat } \\
\text { memuaskan }\end{array}$} & & \\
\hline & & $\mathbf{F}$ & $\%$ & $\mathbf{F}$ & $\%$ & $\mathbf{F}$ & $\%$ & $\mathbf{F}$ & $\%$ & $\mathbf{F}$ & $\%$ & $\mathbf{F}$ & $\%$ \\
\hline 8 & $\begin{array}{l}\text { Security, petugas pendaftaran, } \\
\text { kasir dan apoteker melayani } \\
\text { kedatangan pasien dan keluarga } \\
\text { pasien dengan Cepat,Tanggap, } \\
\text { Ramah,dan Sopan }\end{array}$ & 0 & 0 & 0 & 0.0 & 3 & 10.0 & 22 & 73.3 & 5 & 16.7 & 30 & 100 \\
\hline 9 & Dokter datang Tepat Waktu & 0 & 0 & 2 & 6.7 & 20 & 66.7 & 4 & 13.3 & 4 & 13.3 & 30 & 100 \\
\hline 10 & Kesiapan Dokter melayani pasien & 0 & 0 & 0 & 0.0 & 3 & 10.0 & 22 & 73.3 & 5 & 16.7 & 30 & 100 \\
\hline 11 & Dokter bertindak Cepat & 0 & 0 & 0 & 0.0 & 4 & 13.3 & 21 & 70.0 & 5 & 16.7 & 30 & 100 \\
\hline 12 & $\begin{array}{l}\text { Kesiapan perawat melayani pasien } \\
\text { setiap saat }\end{array}$ & 0 & 0 & 0 & 0.0 & 6 & 20.0 & 20 & 66.7 & 4 & 13.3 & 30 & 100 \\
\hline 13 & $\begin{array}{l}\text { Perawat melaporkan segala detail } \\
\text { perubahan pasien kepada dokter } \\
\text { sewaktu melakukan kunjungan }\end{array}$ & 0 & 0 & 0 & 0.0 & 3 & 10.0 & 25 & 83.3 & 2 & 6.7 & 30 & 100 \\
\hline 14 & $\begin{array}{l}\text { Perawat selalu memberikan obat } \\
\text { pasien sesuai prosedur pemberian } \\
\text { obat }\end{array}$ & 0 & 0 & 0 & 0.0 & 3 & 10.0 & 24 & 80.0 & 3 & 10.0 & 30 & 100 \\
\hline 15 & $\begin{array}{l}\text { Perawat memperhatikan keluhan } \\
\text { keluarga Pasien. }\end{array}$ & 0 & 0 & 0 & 0.0 & 4 & 13.3 & 22 & 73.3 & 4 & 13.3 & 30 & 100 \\
\hline 16 & Tersedia dokter Spesialis & 0 & 0 & 0 & 0.0 & 3 & 10.0 & 6 & 20.0 & 21 & 70.0 & 30 & 100 \\
\hline 17 & $\begin{array}{l}\text { Perilaku Dokter menimbulkan rasa } \\
\text { aman }\end{array}$ & 0 & 0 & 0 & 0.0 & 3 & 10.0 & 22 & 73.3 & 5 & 16.7 & 30 & 100 \\
\hline 18 & $\begin{array}{l}\text { Perawat terdidik dan mampu } \\
\text { melayani pasien }\end{array}$ & 0 & 0 & 0 & 0.0 & 1 & 3.3 & 23 & 76.7 & 6 & 20.0 & 30 & 100 \\
\hline 19 & Biaya perawatan terjangkau & 0 & 0 & 0 & 0.0 & 2 & 6.7 & 24 & 80.0 & 4 & 13.3 & 30 & 100 \\
\hline 20 & $\begin{array}{l}\text { Memberikan jaminan atas } \\
\text { kesembuhan pasien }\end{array}$ & 0 & 0 & 0 & 0.0 & 5 & 16.7 & 20 & 66.7 & 5 & 16.7 & 30 & 100 \\
\hline 21 & $\begin{array}{l}\text { Dokter berusaha menenangkan } \\
\text { rasa cemas pasien terhadap } \\
\text { penyakit yang diderita }\end{array}$ & 0 & 0 & 0 & 0.0 & 3 & 10.0 & 21 & 70.0 & 6 & 20.0 & 30 & 100 \\
\hline 22 & $\begin{array}{l}\text { Perawat meluangkan waktu } \\
\text { khusus untuk berkomunikasi } \\
\text { dengan pasien }\end{array}$ & 0 & 0 & 0 & 0.0 & 3 & 10.0 & 22 & 73.3 & 5 & 16.7 & 30 & 100 \\
\hline 23 & $\begin{array}{l}\text { Perawat, Security dan Cleaning } \\
\text { Service selalu mengingatkan } \\
\text { keamanan akan menyimpan } \\
\text { barang berharga pasien dan } \\
\text { keluarganya }\end{array}$ & 0 & 0 & 0 & 0.0 & 3 & 10.0 & 21 & 70.0 & 6 & 20.0 & 30 & 100 \\
\hline 24 & $\begin{array}{l}\text { Waktu untuk berkonsultasi } \\
\text { keluarga pasien terpenuhi }\end{array}$ & 0 & 0 & 0 & 0.0 & 4 & 13.3 & 22 & 73.3 & 4 & 13.3 & 30 & 100 \\
\hline 25 & $\begin{array}{l}\text { Menghibur dan memberikan } \\
\text { dorongan kepada pasien supaya } \\
\text { cepat sembuh dan mendoakan } \\
\text { mereka }\end{array}$ & 0 & 0 & 0 & 0.0 & 3 & 10.0 & 21 & 70.0 & 6 & 20.0 & 30 & 100 \\
\hline
\end{tabular}

Berdasarkan tabel 1 diatas menunjukkan bahwa pelayanan yang sangat memuaskan bagi pasien Klinik Jantung Hasna Medika Indramayu yaitu tersedia dokter spesialis $\quad(70,0 \%), \quad$ sementara yang memuaskan bagi pasien diantaranya adalah penampilan dokter, perawat dan karyawan lainnya bersih dan rapih $(88,3 \%)$, memiliki alat-alat medis/kesehatan yang cukup lengkap $(73,3 \%)$, kenyaman di ruangan kontrol dokter 
Meddy Nurpratama

dan ruang rawat inap (66,7\%), kebersihan dan keamanan di ruang lingkup dalam dan di luar klinik $(66,7 \%)$, security, petugas pendaftaran, kasir dan apoteker melayani kedatangan pasien dan keluarga pasien dengan cepat,tanggap, ramah,dan sopan $(73,3 \%)$, kesiapan dokter melayani pasien $(73,3 \%)$, dokter bertindak cepat $(70,0 \%)$, kesiapan perawat melayani pasien setiap saat $(66,7 \%)$, perawat melaporkan segala detail perubahan pasien kepada dokter sewaktu melakukan kunjungan (83,3\%), perawat selalu memberikan obat pasien sesuai prosedur pemberian obat $(80,0 \%)$, perawat memperhatikan keluhan keluarga pasien (73,3\%), perilaku dokter menimbulkan rasa aman $(73,3 \%)$, perawat terdidik dan mampu melayani pasien $(76,7 \%)$, biaya perawatan terjangkau $(80,0 \%)$, memberikan jaminan atas kesembuhan pasien $(66,7 \%)$, dokter berusaha menenangkan rasa cemas pasien terhadap penyakit yang diderita $(70,0 \%)$, perawat meluangkan waktu khusus untuk berkomunikasi dengan pasien (73,3\%), perawat, security dan cleaning service selalu mengingatkan keamanan akan menyimpan barang berharga pasien dan keluarganya
(70,0\%), waktu untuk berkonsultasi keluarga pasien terpenuhi $(73,3 \%)$ dan menghibur dan memberikan dorongan kepada pasien supaya cepat sembuh dan mendoakan mereka (70,0\%). Adapun beberapa item yang kurang memuaskan bagi pasien rawat jalan di Klinik Jantung Hasna Medika Indramayu diantaranya adalah waktu pelayanan dan kenyamanan ruang tunggu (66,7\%), kelengkapan fasilitas di ruang tunggu pasien $(70,0 \%)$, prosedur penerimaan pasien dilayani secara cepat dan tidak berbelit-belit $(73,3 \%)$ dan dokter datang tepat waktu $(66,7 \%)$. Dengan demikian maka sebagian besar bahwa pelayanan di ruang rawat jalan Klinik Jantung Hasna Medika Indramayu dapat dikatakan sudah memuaskan, namun ada beberapa pelayanan yang perlu diperbaiki karena dipandang pasien masih kurang memuaskan yaitu pada aspek waktu pelayanan dan kenyamanan ruang tunggu, kelengkapan fasilitas di ruang tunggu pasien, prosedur penerimaan pasien dilayani secara cepat dan tidak berbelit-belit dan dokter datang tepat waktu. Untuk lebih jelasnya dapat dilihat pada gambar 2 . 
Meddy Nurpratama

Gambar 2

Persentase Item Berdasarkan Tanggapan Responden Rawat Jalan tentang Pelayanan di Klinik Jantung Hasna Medika Indramayu

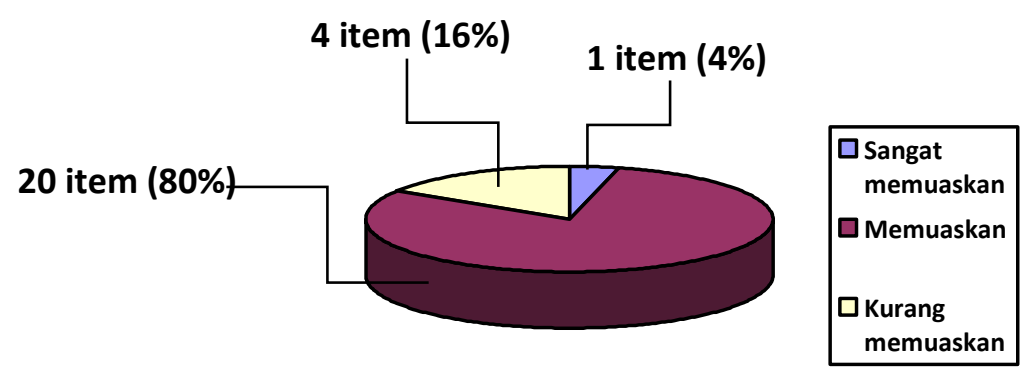

Berdasarkan gambar 1, maka sebanyak 20 item $(80 \%)$ yang memuaskan pasien responden rawat jalan tentang pelayanan di Klinik Jantung Hasna Medika Indramayu, dan ada 1 item (4\%) yang sangat memuaskan sedangkan yang kurang memuaskan dan perlu diperbaiki ada 4 item (16\%) pelayanan di ruang rawat jalan Klinik Jantung Hasna Medika Indramayu

Selanjutnya gambaran tentang kepuasan pasien rawat inap di Klinik Jantung Hasna Medika Indramayu dapat dilihat pada tabel 2.

Tabel 2

Distribusi Frekuensi Tanggapan Responden Rawat Inap tentang Pelayanan di Klinik Jantung Hasna Medika Indramayu

\begin{tabular}{|c|c|c|c|c|c|c|c|c|c|c|c|c|c|}
\hline \multirow{3}{*}{ No. } & \multirow{3}{*}{ Pertanyaan } & \multicolumn{10}{|c|}{ Jawaban } & \multirow{2}{*}{\multicolumn{2}{|c|}{$\begin{array}{l}\text { Jumlah } \\
\text { Total }\end{array}$}} \\
\hline & & \multicolumn{2}{|c|}{\begin{tabular}{|c|} 
Sangat \\
Tidak \\
Memuaskan
\end{tabular}} & \multicolumn{2}{|c|}{$\begin{array}{c}\text { Tidak } \\
\text { Memuaskan }\end{array}$} & \multicolumn{2}{|c|}{$\begin{array}{c}\text { Kurang } \\
\text { Memuask } \\
\text { an }\end{array}$} & \multicolumn{2}{|c|}{ Memuaskan } & \multicolumn{2}{|c|}{$\begin{array}{c}\text { Sangat } \\
\text { memuaskan }\end{array}$} & & \\
\hline & & $\mathbf{F}$ & $\%$ & $\mathbf{F}$ & $\%$ & $\mathbf{F}$ & $\%$ & $\mathbf{F}$ & $\%$ & $\mathbf{F}$ & $\%$ & $\mathbf{F}$ & $\%$ \\
\hline 1 & $\begin{array}{l}\text { Waktu Pelayanan dan } \\
\text { Kenyamanan Ruang Tunggu }\end{array}$ & 0 & 0 & 0 & 0.0 & 1 & 3.3 & 5 & 16.7 & 24 & 80.0 & 30 & 100 \\
\hline 2 & $\begin{array}{l}\text { Penampilan Dokter, Perawat dan } \\
\text { Karyawan lainnya Bersih dan } \\
\text { Rapih }\end{array}$ & 0 & 0 & 0 & 0.0 & 1 & 3.3 & 25 & 83.3 & 4 & 13.3 & 30 & 100 \\
\hline 3 & $\begin{array}{l}\text { Kelengkapan Fasilitas di Ruang } \\
\text { Tunggu Pasien }\end{array}$ & 0 & 0 & 0 & 0.0 & 1 & 3.3 & 24 & 80.0 & 5 & 16.7 & 30 & 100 \\
\hline 4 & $\begin{array}{l}\text { Memiliki alat-alat } \\
\text { Medis/kesehatan yang cukup } \\
\text { lengkap }\end{array}$ & 0 & 0 & 0 & 0.0 & 2 & 6.7 & 22 & 73.3 & 6 & 20.0 & 30 & 100 \\
\hline 5 & $\begin{array}{l}\text { Kenyaman di Ruangan Kontrol } \\
\text { Dokter dan ruang rawat inap }\end{array}$ & 0 & 0 & 0 & 0.0 & 3 & 10.0 & 23 & 76.7 & 4 & 13.3 & 30 & 100 \\
\hline 6 & $\begin{array}{l}\text { Kebersihan dan Keamanan di } \\
\text { ruang lingkup dalam dan di luar } \\
\text { klinik }\end{array}$ & 0 & 0 & 0 & 0.0 & 1 & 3.3 & 25 & 83.3 & 4 & 13.3 & 30 & 100 \\
\hline 7 & $\begin{array}{l}\text { Prosedur penerimaan pasien } \\
\text { dilayani secara cepat dan tidak } \\
\text { berbelit-belit }\end{array}$ & 0 & 0 & 0 & 0.0 & 1 & 3.3 & 4 & 13.3 & 25 & 83.3 & 30 & 100 \\
\hline 8 & $\begin{array}{l}\text { Security, petugas pendaftaran, } \\
\text { kasir dan apoteker melayani } \\
\text { kedatangan pasien dan keluarga } \\
\text { pasien dengan Cepat,Tanggap, }\end{array}$ & 0 & 0 & 0 & 0.0 & 1 & 3.3 & 24 & 80.0 & 5 & 16.7 & 30 & 100 \\
\hline
\end{tabular}


Meddy Nurpratama

\begin{tabular}{|c|c|c|c|c|c|c|c|c|c|c|c|c|c|}
\hline \multirow{3}{*}{ No. } & \multirow{3}{*}{ Pertanyaan } & \multicolumn{10}{|c|}{ Jawaban } & \multirow{2}{*}{\multicolumn{2}{|c|}{$\begin{array}{c}\text { Jumlah } \\
\text { Total }\end{array}$}} \\
\hline & & \multicolumn{2}{|c|}{\begin{tabular}{|c|} 
Sangat \\
Tidak \\
Memuaskan
\end{tabular}} & \multicolumn{2}{|c|}{$\begin{array}{c}\text { Tidak } \\
\text { Memuaskan }\end{array}$} & \multicolumn{2}{|c|}{$\begin{array}{c}\text { Kurang } \\
\text { Memuask } \\
\text { an } \\
\end{array}$} & \multicolumn{2}{|c|}{ Memuaskan } & \multicolumn{2}{|c|}{$\begin{array}{c}\text { Sangat } \\
\text { memuaskan }\end{array}$} & & \\
\hline & & $\mathbf{F}$ & $\%$ & $\mathbf{F}$ & $\%$ & $\mathbf{F}$ & $\%$ & $\mathbf{F}$ & $\%$ & $\mathbf{F}$ & $\%$ & $\mathbf{F}$ & $\%$ \\
\hline & Ramah,dan Sopan & & & & & & & & & & & & \\
\hline 9 & Dokter datang Tepat Waktu & 0 & 0 & 0 & 0.0 & 4 & 13.3 & 4 & 13.3 & 22 & 73.3 & 30 & 100 \\
\hline 10 & $\begin{array}{l}\text { Kesiapan Dokter melayani } \\
\text { pasien }\end{array}$ & 0 & 0 & 0 & 0.0 & 0 & 0.0 & 25 & 83.3 & 5 & 16.7 & 30 & 100 \\
\hline 11 & Dokter bertindak Cepat & 0 & 0 & 0 & 0.0 & 1 & 3.3 & 23 & 76.7 & 6 & 20.0 & 30 & 100 \\
\hline 12 & $\begin{array}{l}\text { Kesiapan perawat melayani } \\
\text { pasien setiap saat }\end{array}$ & 0 & 0 & 0 & 0.0 & 1 & 3.3 & 22 & 73.3 & 7 & 23.3 & 30 & 100 \\
\hline 13 & $\begin{array}{l}\text { Perawat melaporkan segala } \\
\text { detail perubahan pasien kepada } \\
\text { dokter sewaktu melakukan } \\
\text { kunjungan }\end{array}$ & 0 & 0 & 1 & 3.3 & 4 & 13.3 & 20 & 66.7 & 5 & 16.7 & 30 & 100 \\
\hline 14 & $\begin{array}{l}\text { Perawat selalu memberikan obat } \\
\text { pasien sesuai prosedur } \\
\text { pemberian obat }\end{array}$ & 0 & 0 & 0 & 0.0 & 1 & 3.3 & 25 & 83.3 & 4 & 13.3 & 30 & 100 \\
\hline 15 & $\begin{array}{l}\text { Perawat memperhatikan keluhan } \\
\text { keluarga Pasien. }\end{array}$ & 0 & 0 & 0 & 0.0 & 2 & 6.7 & 22 & 73.3 & 6 & 20.0 & 30 & 100 \\
\hline 16 & Tersedia dokter Spesialis & 0 & 0 & 0 & 0.0 & 0 & 0.0 & 26 & 86.7 & 4 & 13.3 & 30 & 100 \\
\hline 17 & $\begin{array}{l}\text { Perilaku Dokter menimbulkan } \\
\text { rasa aman }\end{array}$ & 0 & 0 & 0 & 0.0 & 2 & 6.7 & 22 & 73.3 & 6 & 20.0 & 30 & 100 \\
\hline 18 & $\begin{array}{l}\text { Perawat terdidik dan mampu } \\
\text { melayani pasien }\end{array}$ & 0 & 0 & 0 & 0.0 & 3 & 10.0 & 22 & 73.3 & 5 & 16.7 & 30 & 100 \\
\hline 19 & Biaya perawatan terjangkau & 0 & 0 & 0 & 0.0 & 5 & 16.7 & 20 & 66.7 & 5 & 16.7 & 30 & 100 \\
\hline 20 & $\begin{array}{l}\text { Memberikan jaminan atas } \\
\text { kesembuhan pasien }\end{array}$ & 0 & 0 & 0 & 0.0 & 3 & 10.0 & 21 & 70.0 & 6 & 20.0 & 30 & 100 \\
\hline 21 & $\begin{array}{l}\text { Dokter berusaha menenangkan } \\
\text { rasa cemas pasien terhadap } \\
\text { penyakit yang diderita }\end{array}$ & 0 & 0 & 0 & 0.0 & 3 & 10.0 & 20 & 66.7 & 7 & 23.3 & 30 & 100 \\
\hline 22 & $\begin{array}{l}\text { Perawat meluangkan waktu } \\
\text { khusus untuk berkomunikasi } \\
\text { dengan pasien }\end{array}$ & 0 & 0 & 0 & 0.0 & 3 & 10.0 & 22 & 73.3 & 5 & 16.7 & 30 & 100 \\
\hline 23 & $\begin{array}{l}\text { Perawat, Security dan Cleaning } \\
\text { Service selalu mengingatkan } \\
\text { keamanan akan menyimpan } \\
\text { barang berharga pasien dan } \\
\text { keluarganya }\end{array}$ & 0 & 0 & 0 & 0.0 & 1 & 3.3 & 24 & 80.0 & 5 & 16.7 & 30 & 100 \\
\hline 24 & $\begin{array}{l}\text { Waktu untuk berkonsultasi } \\
\text { keluarga pasien terpenuhi }\end{array}$ & 0 & 0 & 0 & 0.0 & 1 & 3.3 & 25 & 83.3 & 4 & 13.3 & 30 & 100 \\
\hline 25 & $\begin{array}{l}\text { Menghibur dan memberikan } \\
\text { dorongan kepada pasien supaya } \\
\text { cepat sembuh dan mendoakan } \\
\text { mereka }\end{array}$ & 0 & 0 & 0 & 0.0 & 2 & 6.7 & 22 & 73.3 & 6 & 20.0 & 30 & 100 \\
\hline
\end{tabular}

Berdasarkan tabel 2 menunjukkan bahwa pelayanan pada pasien rawat inap sudah memuaskan karena berdasarkan tanggapan responden menggambarkan kepuasan pasien adalah sangat memuaskan dan memuaskan, sedangkan yang 
Meddy Nurpratama

memberikan jawaban sangat tidak memuaskan, tidak memuaskan dan kurang memuaskan relatif sedikit atau bahkan tidak ada. Item yang sangat memuaskan bagi pasien yaitu waktu pelayanan dan kenyamanan ruang tunggu $(80,0 \%)$, prosedur penerimaan pasien dilayani secara cepat dan tidak berbelit-belit $(83,3 \%)$ dan dokter datang tepat waktu (73,3\%). Sedangkan item lainnya memuaskan bagi pasien rawat inap di Klinik Jantung Hasna Medika Indramayu, yaitu tersedia dokter spesialis dengan persentase $86,7 \%$, Penampilan Dokter, Perawat dan Karyawan lainnya Bersih dan Rapih, Kebersihan dan Keamanan di ruang lingkup dalam dan di luar klinik, Kesiapan Dokter melayani pasien, Perawat selalu memberikan obat pasien sesuai prosedur pemberian obat, Waktu untuk berkonsultasi keluarga pasien terpenuhi dengan persentase $83,3 \%$. Kelengkapan fasilitas di ruang tunggu pasien, security, petugas pendaftaran, kasir dan apoteker melayani kedatangan pasien dan keluarga pasien dengan cepat,tanggap, ramah,dan sopan, perawat, security dan cleaning service selalu mengingatkan keamanan akan menyimpan barang berharga pasien dan 


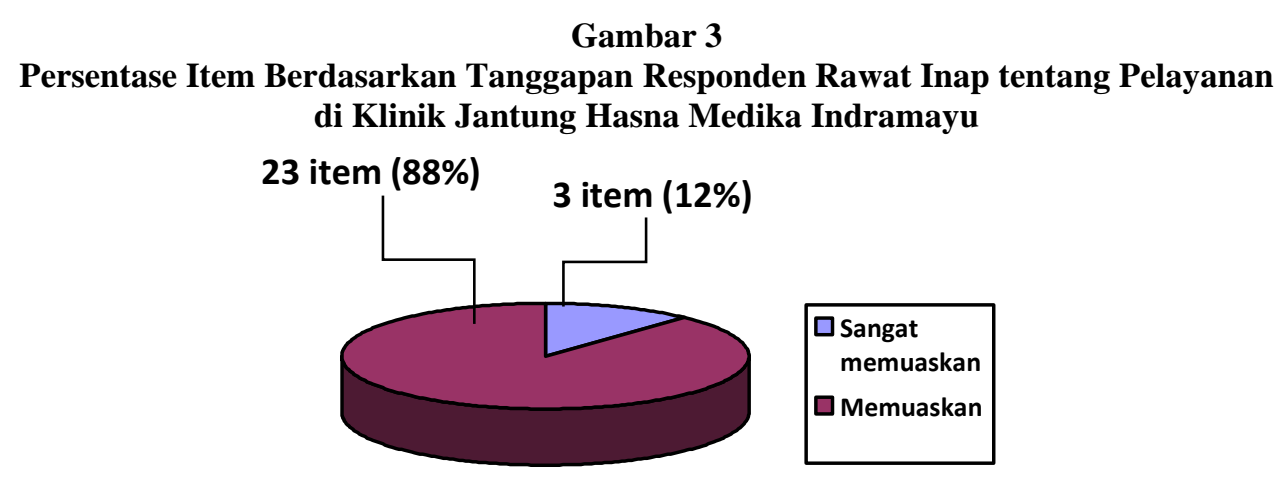

Berdasarkan diagram di atas, maka sebanyak 23 item (88\%) yang memuaskan pasien responden rawat inap tentang Pelayanan di Klinik Jantung Hasna Medika Indramayu, dan 3 item (12\%) yang sangat memuaskan pasien responden rawat inap tentang Pelayanan di Klinik Jantung Hasna Medika Indramayu.

\section{Pembahasan}

Berdasarkan hasil survei yang telah dilakukan kepuasan paling tinggi pada pelayanan di rawat jalan Klinik Jantung Hasna Medika Indramayu yaitu penampilan dokter, perawat dan karyawan lainnya bersih dan rapih $(88,3 \%)$ sedangkan kepuasan tertinggi pada pelayanan di rawat inap Klinik Jantung Hasna Medika Indramayu yaitu prosedur penerimaan pasien dilayani secara cepat dan tidak berbelit-belit $(83,3 \%)$. Sebagian besar pelayanan ndi Klinik Jantung Hasna Medika Indramayu pada rawat inap maupun rawat jalannya telah memuaskan pasien. Pasien merasa puas terhadap pelayanan yang diberikan oleh tenaga kesehatan dan dokter, pelayanan waktu registrasi, waktu pelayanan di Klinik Jantung Hasna Medika Indramayu. Namun, dari hasil survei terdapat beberapa item yang menunjukkan kurang memuaskan khususnya pada pelayanan rawat jalan yaitu pada aspek waktu pelayanan dan kenyamanan ruang tunggu, kelengkapan fasilitas di ruang tunggu pasien, prosedur penerimaan pasien dilayani secara cepat dan tidak berbelit-belit dan dokter datang tepat waktu. Keempat aspek ini perlu menjadi bahan kajian dan evaluasi oleh Klinik Jantung Hasna Medika Indramayu. Hal ini dapat dikarenakan ruang tunggu kurang nyaman karena antrian sangat panjang, dokter sering telat, pelayanan mengambil obat sangat lama, dan kebersihan di ruang tunggu rawat jalan mohon ditingkatkan lagi.

Kepuasan pasien ini dapat dipengaruhi oleh beberapa faktor. Berikut adalah faktorfaktor yang mempengaruhi rendahnya penilaian dan kepuasan pasien: Menurut Rahadi tahun 2005 perlakuan perawat yang tidak menyenangkan pasien antara lain kurang ramah pada pasien, tidak cepat melayani 
Meddy Nurpratama

pasien, kurang mampu berkomunikasi dengan baik (Rahadi, 2005). Sedangkan menurut Tjiptono dalam Purwanto tahun 2007 komunikasi, yaitu tata cara informasi yang diberikan pihak penyedia jasa dan keluhankeluhan dari pasien. Kepuasan dari pasien yang melakukan pemeriksaan dapat tercipta dengan cara bagaimana keluhan dengan cepat dapat diterima oleh penyedia pelayanan jasa terutama perawat dan dokter dalam memberikan bantuan terhadap keluhan pasien (Purwanto, 2007).

Menurut Griffith dalam Purwanto tahun 2007 prosedur administrasi yaitu berkaitan dengan pelayanan administrasi pasien mulai masuk pelayanan kesehatan, selama perawatan berlangsung sampai keluar pelayanan kesehatan tersebut (Purwanto, 2007). Salah satu faktor yang mempengaruhi kualitas jasa pelayanan, terutama bagi mereka yang berinteraksi langsung dengan pelanggan eksternal adalah kesopanan dan keramahan dalam memberi pelayanan (Yulia, 2008).

Menurut Rahadi tahun 2005 perlakuan dokter yang tidak menyenangkan pasien salah satunya adalah kurang mampu berkomunikasi dengan baik (Rahadi, 2005). Hal ini dapat menimbulkan ketidakpuasan pasien. Menurut Pohan dalam Yulia tahun 2008 para dokter mempunyai kemampuan sehingga mereka dapat sangat mengurangi tekanan psikologis pasien, hanya dengan beberapa kata penenang dan penghibur dengan menunjukkan perhatian dan keterlibatan dalam kesulitan pasien
(Yulia, 2008). Menurut Tjiptono dalam Purwanto pasien didapatkan salah satunya melalui kecepatan yaitu pelayanan perawat melalui pemberian penanganan pasien yang cepat (Purwanto, 2007).

Hasil survei yang dilakukan di Klinik Jantung Hasna Medika Indramayu selaras dengan hasil penelitian Soelarso tahun 2006 yang menyebutkan kemampuan dokter dalam menciptakan hubungan interpersonal dengan pasien akan membangun komunikasi antara dokter dan pasien menjadi lebih optimal (Soelarso, 2006). Menurut pasien, kecepatan akses memperoleh pelayanan sangat penting pada pelayanan yang berhubungan dengan jasa (Primalita, 2005). Hasil penelitian Hartini tahun 1999 menyatakan bahwa ada hubungan positif antara kepuasan pasien terhadap kecepatan pelayanan administrasi di tempat pelayanan kesehatan, ada hubungan positif antara kepuasan pasien dengan fasilitas/sarana fisik dan pelayanan perawat di tempat pelayanan kesehatan. Sedangkan Hariyanto tahun 2005 menyimpulkan bahwa terdapat pengaruh antara kepuasan pasien dengan kecepatan waktu pelayanan di apotik (Hariyanto, 2005).

Hasil penelitian Wiyono dan Wahyuddin tahun 2006 yang menyatakan bahwa kualitas pelayanan paramedis memiliki pengaruh terbesar terhadap mutu dan kenyamanan pada tempat pelayanan kesehatan (Wiyono dan Wahyuddin, 2006). Sedangkan menurut penelitian Lamri tahun 
Meddy Nurpratama

1988 berpendapat kebersihan berpengaruh kuat dan positif pada kepuasan pasien (Lamri, 1998).

\section{KESIMPULAN}

Pencapaian kepuasan tertinggi pada pelayanan rawat jalan di Klinik Jantung Hasna Medika Indramayu yaitu penampilan dokter, perawat dan karyawan lainnya bersih dan rapih $(88,3 \%)$ sedangkan rawat inap yaitu prosedur penerimaan pasien dilayani secara cepat dan tidak berbelit-belit (83,3\%). Sebagian besar pelayanan di Klinik Jantung Hasna Medika Indramayu baik rawat jalan maupun rawat inap sudah memuaskan pasien. Sementara pelayanan yang kurang memuaskan terdapat pada pelayanan rawat jalan yaitu waktu pelayanan dan kenyamanan ruang tunggu, kelengkapan fasilitas di ruang tunggu pasien, prosedur penerimaan pasien dilayani secara cepat dan tidak berbelit-belit dan dokter datang tepat waktu.

\section{Saran}

Pelayanan di Klinik Jantung Hasna Medika Indramayu sudah memuaskan, namun hendaknya disediakan kotak saran dengan lembar kepuasan yang dapat diisi oleh pasien, selanjutnya untuk pelayanan di rawat jalan perlu adanya perbaikan di ruang tunggu seperti memperlebar ruangan dan memperbaikan antrian pasien dengan mengutamakan pasien yang datar terlebih dahulu sehingga lebih teratur dan tidak menimbulkan antrian yang panjang, melengkapi kelengkapan fasilitas di ruang tunggu pasien, memperbaikan prosedur penerimaan pasien dan memberikan himbauan dokter untuk datang tepat waktu. Serta diharapkan di masa depan, dilakukan penelitian lanjutan tentang aspek yang lebih luas di Klinik Jantung Hasna Medika Indramayu.

\section{DAFTAR PUSTAKA}

Hariyanto, K. N, Supardi, S. Kepuasan Pasien Terhadap Pelayanan Resep di Apotek KopKar Rumah Sakit Budi Asih Jakarta. Majalah Ilmu Kefarmasian. Vol.2:12-21，2005;Supriyanto, S., Wulandari, R.D. Manajemen Mutu Pelayanan Kesehatan. Surabaya: Pohon Cahaya. 2011;

Inge HM, Sanusi R. Hubungan Penempatan Dokter Umum sebagai Case Manager dan Kepuasan Pasien di Ruang Rawat Inap RS. St. Elisabeth. Jurnal Managemen Pelayanan Kesehatan.Sower V. Quality Management Text Manuscript. n.p. 2006;

Lamri, Iman S. Pengaruh Kualitas Pelayanan Terhadap Kepuasan Minat Perilaku Penderita Rawat Inap di Rumah Sait Islam Samarinda. Jurbal Manajemen Pelayanan Kesehatan. Vol 01:41, 1998.

Primalita R. Hubungan Physical Support dengan Contact Personel pada Rumah Sakit Umum di Sumatra Barat. [Bandung]: Universitas Padjajaran. 2005; 
Purwanto S. Kepuasan Pasien terhadap Pelayanan Rumah Sakit. Artikel Psikologi Klinis Perkembangan dan Sosial. 2007;

Rahadi AR. Upaya Pemasaran Guna Meningkatkan Pemanfaatan Rawat Inap Bedasarkan Analisis Perilaku Konsumen di Rumah Sakit Daerah Dr. H. Moh. Anwar Kabupaten Sumenep. [Surabaya]: Airlangga. 2005;

Soelarso H, Soebekti RH, Mufid A. Peran komunikasi interpersonal dalam pelayanan kesehatan gigi (The role of interpersonal communication integrated with medical dental care). Dental Journal (Majalah Kedokteran Gigi). 2006.

Wiyono AS, Wahyuddin M. Studi Tentang Kualitas Pelayanan dan Kepuasan Konsumen di Rumah Sakit Islam Manisrenggo Klaten. Jurgal Manajemen Daya Saing. 2005;

Yulia SM. Analisis Harapan dan Penilaian Pasien terhadap Kualitas Pelayanan Dokter, Doker Muda, Perawat dan Petugas Registrasi Berdasar Sepuluh Dimensi Kualitas jasa para Suranman. [Surabaya]: Universitas Airlangga. 2008; 